\title{
Allometric models and aboveground biomass stocks of a West African Sudan Savannah watershed in Benin
}

Adéyèmi Chabi ${ }^{1,5^{*}}$, Sven Lautenbach², Vincent Oladokoun Agnila Orekan ${ }^{3}$ and Nicholas Kyei-Baffour 4,5

\begin{abstract}
Background: The estimation of forest biomass changes due to land-use change is of significant importance for estimates of the global carbon budget. The accuracy of biomass density maps depends on the availability of reliable allometric models used in combination with data derived from satellites images and forest inventory data. To reduce the uncertainty in estimates of carbon emissions resulting from deforestation and forest degradation, better information on allometric equations and the spatial distribution of aboveground biomass stocks in each land use/land cover (LULC) class is needed for the different ecological zones. Such information has been sparse for the West African Sudan Savannah zone. This paper provides new data and results for this important zone. The analysis combines satellite images and locally derived allometric models based on non-destructive measurements to estimate aboveground biomass stocks at the watershed level in the Sudan Savannah zone in Benin.

Results: We compared three types of empirically fitted allometric models of varying model complexity with respect to the number of input parameters that are easy to measure at the ground: model type I based only on the diameter at breast height (DBH), type II which used DBH and tree height and model type III which used DBH, tree height and wood density as predictors. While for most LULC classes model III outperformed the other models even the simple model I showed a good performance. The estimated mean dry biomass density values and attached standard error for the different LULC class were $3.28 \pm 0.31$ (for cropland and fallow), $3.62 \pm 0.36$ (for Savanna grassland), $4.86 \pm 1.03$ (for Settlements), $14.05 \pm 0.72$ (for Shrub savanna), 45.29 \pm 2.51 (for Savanna Woodland), $46.06 \pm 14.40$ (for Agroforestry), $94.58 \pm 4.98$ (for riparian forest and woodland), $162 \pm 64.88$ (for Tectona grandis plantations), $179.62 \pm 57.61$ (for Azadirachta indica plantations), $25.17 \pm 7.46$ (for Gmelina arborea plantations), to $204.92 \pm 57.69$ (for Eucalyptus grandis plantations) $\mathrm{Mg} \mathrm{ha}^{-1}$. The higher uncertainty of agroforestry system and plantations is due to the variance in age which affects biomass stocks.
\end{abstract}

Conclusion: The results from this study help to close the existing knowledge gap with respect to biomass allometric models at the watershed level and the estimation of aboveground biomass stocks in each LULC in the Sudan Savannah in West Africa. The use of model type I, which relies only on the easy to measure DBH, seems justified since it performed almost as good as the more complex model types II and III. The work provided useful data on wood density of the main species of the Sudan Savannah zone, the related local derived biomass expansion factor and the biomass density in each LULC class that would be an indispensable information tool for carbon accounting programme related to the implementation of the Kyoto Protocol and REDD+ (reducing emissions from deforestation and forest degradation, and forests conservation, sustainable management of forests, and enhancement of forest carbon stocks) initiatives.

\footnotetext{
*Correspondence: princechabi@gmail.com

1 Department of Civil Engineering, Kwame Nkrumah University of Science and Technology, Kumasi, Ghana

Full list of author information is available at the end of the article
} 
Keywords: Allometric models, Aboveground biomass stocks, West African Sudan Savannah watershed, Nondestructive method, Biomass density, Benin

\section{Background}

The sources and sinks of carbon from land use and land cover change (LULCC) are significant elements in the global carbon budget [1]. Current challenges of forest management are related to verifiable, reliable, accurate and cost-effective methods to adequately document forest resources dynamics [2]. The accuracy of biomass density maps depends on the availability of reliable allometric models to infer aboveground biomass (AGB) of trees from tree census data [3]. Large uncertainties in emission estimates arise from inadequate data on the biomass density of forests and the regional rates of deforestation $[1,4]$. These uncertainties compromise the estimation of terrestrial carbon emissions [5-8] and required knowledge on biomass stocks.

A number of comprehensive allometric models for biomass estimation have been developed for the major tree species in Europe, America and Asia [3, 9-22]. In subSaharan Africa and especially West-African countries, most of the estimation of the total carbon stocks has also used allometric models together with forest inventory data [22-35]. The majority of studies so far have focused on forest ecosystems, specific tree species or plantations for the estimation of AGB and carbon stocks [3, 23, 25, $26,28,31,32,36-46]$. Very few studies have dealt with the estimation of AGB in the agricultural landscapes [35].

Attempts to estimate AGB at the watershed level requires typically satellite images derived LULC information as well as allometric models from each LULC class. The data for allometric models for estimating biomass in woody vegetation comes either from destructive or from non-destructive methods. Destructive methods are based on the harvesting of the living trees together with measurements of diameter at breast height (DBH) or stem girth and total height as well as the dry mass of stem, foliage and branches. The collected variables are then used as input for estimating tree volume and biomass for selected trees species [22, 30, 37, 45, 47]. According to Djomo et al. [25], the application of destructive methods is labour intensive and time consuming. This method is therefore restricted to small trees at small scales [38, 48]. Additionally, harvesting trees requires in general special authorization which is often not easy to acquire especially when the study region involves protected areas.

Recent assessments have switched to the use of non-destructive methods [42, 49-55]. The tools and approaches used thereby vary considerably between regions. A biomass expansion factor (BEF) which expresses the relationship between stem biomass and the total biomass of a single tree species as well as information on wood density of the involved tree species are the keys variables used by allometric models to assess total biomass of living trees. If shape characteristics are included in the estimation of the BEF the approach is similar to the volume based approach in which information on height and diameter of a tree are used together with species specific shape and wood density factors [82]. The importance of wood density for estimating forest biomass and greenhouse-gas emissions from LULCC has been stressed by Nogueira et al. [54]. A variety of different approaches has been applied in case studies worldwide: Montes et al. [53] e.g. estimated the biomass of thuriferous juniper woodland in Morocco based on component volumes estimated from two orthogonalview photographs and the density of each component. This approach is not well suited to estimate biomass in natural environments, especially when the environment is degraded by human use and wood supply for the local populations is at stake. Lehtonen et al. [52] developed expansion factors conditional on stand age and dominant tree species to estimate total biomass of pine trees in Norway. Flombaum and Sala [50] presented an approach for the calibration of a fast non-destructive method to estimate aboveground plant biomass by double-sampling vegetation cover and AGB in the Patagonian steppe. The author fitted linear regression models to describe the relationship between vegetation cover and biomass for the dominant species and life forms. Tackenberg [55] presented a non-destructive method based on scaled digital images analysis of the plants silhouettes, addressing not only aboveground fresh biomass and oven-dried biomass, but also vertical biomass distribution as well as dry matter content and growth rates. The method used by Tackenberg [55] is time and cost effective compared with destructive measurements, especially if development or growth rates are to be measured repeatedly. Another branch of approaches aims at identifying wood volumes by remote sensing approaches [83-86] - however for relating volume estimates with biomass information on wood density for the relevant species is necessary which is missing for many natural and semi-natural tree species in the tropics and sub-tropics.

Two problems hinder the transfer of the currently used non-destructive methods in the West-African context. First, BEFs are not available for most relevant local tree 
species and most devices used in other regions of the world are not suitable. In the southern part of the Republic of Benin, Guendehou et al. [42] assessed stem biomass based on stem volume and wood density for selected tropical tree species using an increment borer as the device of stem wood sample extraction. Unfortunately, the obtained BEF could not be applied in the context of the present study since the study was undertaken under the tropical conditions in West Africa which are different from the conditions in the case study region. The work by Guendehou et al. [42] therefore needs to be expanded to reflect conditions and tree species in different land use systems to allow a more precise estimation of the relevance of African trees for biomass and carbon stocks.

The goal of this paper was to accurately estimate AGB stocks at the watershed level in the Sudan Savannah zone using satellite images derived LULC data and adjusted allometric models based on data from non-destructive method.

\section{Methods}

The AGB estimation at the watershed scale was based on the following steps (Fig. 1):

1. satellite images analysis and LULC classification,

2. forest inventory in each identified LULC class of the watershed,

3. trees communities analysis and identification of the main species of the watershed based on importance value index (IVI),

4. estimation of basic wood density and BEF model of selected species,

5. assessment of non-destructive method to the destructive one based on available data,

6. development of allometric models using DBH, tree height and basic wood density of main trees species,

7. calculation of biomass data at the tree and the plot level using the best allometric equations of each LUCa and extrapolation at the watershed level,

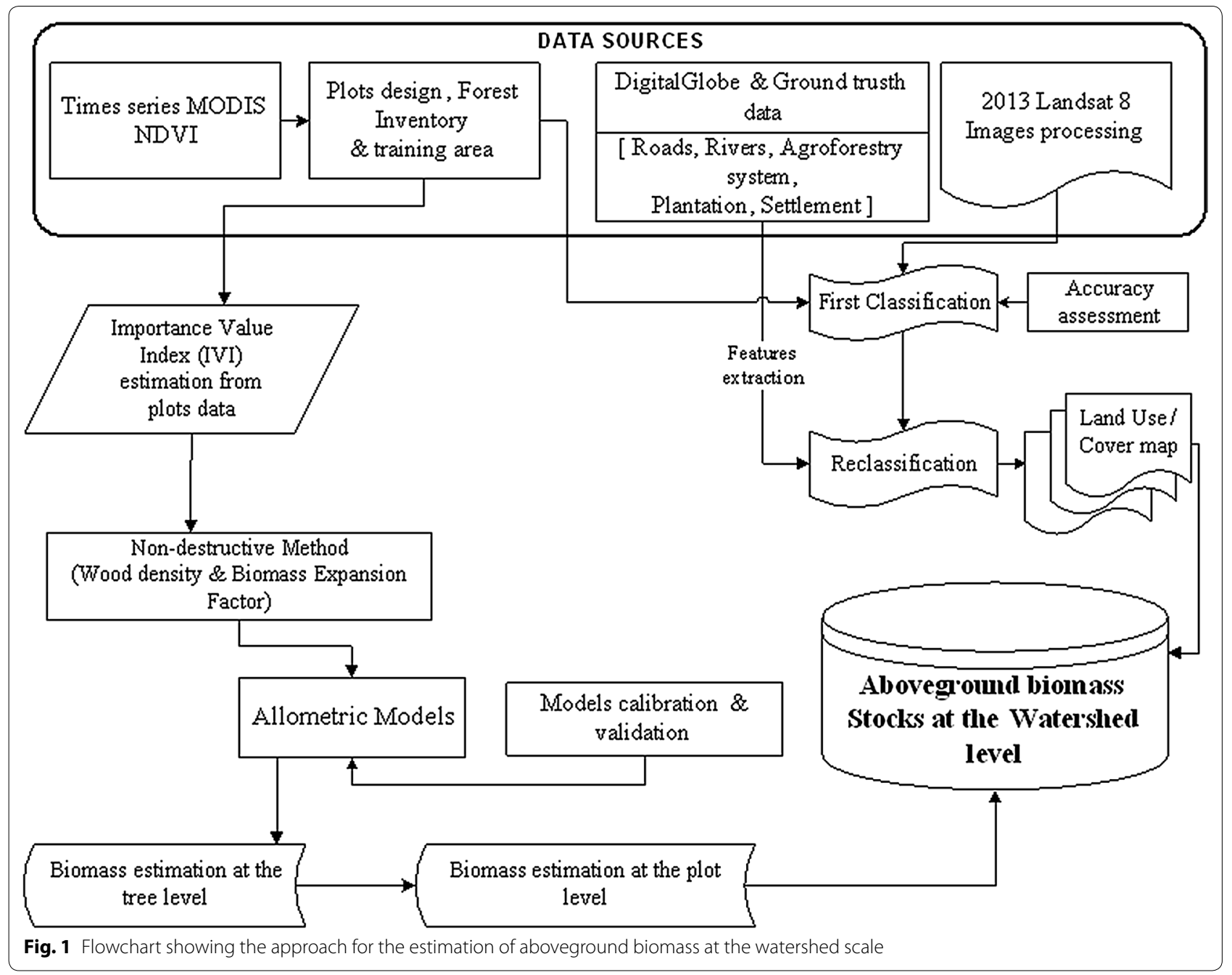


8. mapping the biomass density using ArcGIS 10.2.1 software.

\section{Site location}

The analysis took place in the Dassari basin situated in North-West of Benin (Fig. 2) and covers an area of $192.57 \mathrm{~km}^{2}$. The site is located between $10^{\circ} 44^{\prime} 08^{\prime \prime}$ and $10^{\circ} 55^{\prime} 42^{\prime \prime}$ North and $1^{\circ} 01^{\prime} 32^{\prime \prime}$ and $1^{\circ} 11^{\prime} 30^{\prime \prime}$ East.

Long-term (1952-2010) minimal daily temperature at Natitingou station located $50 \mathrm{~km}$ from the site ranged from 15.25 to $25.08{ }^{\circ} \mathrm{C}$ with an average of $20.53{ }^{\circ} \mathrm{C}$. Daily maximum temperature ranged from 26.63 to $39.27{ }^{\circ} \mathrm{C}$ with a mean temperature of $32.59^{\circ} \mathrm{C}$. Long-term (19712013) mean monthly precipitation for Tanguieta station (15-20 km from the study area) was $87.5 \mathrm{~mm}$.

We used the standardized precipitation index (SPI) programme developed by Brown [68] and the result showed two periods (1978-1979; 1985-1986) of extreme drought with some years of moderate to severe drought during these 42 years of observation.

\section{Data collection}

\section{Data sources for images classification}

The estimation of aboveground tree biomass at the watershed scale was complicated by the heterogeneous tree species distribution across the different LUCa. Two Landsat 8 scenes (http://glovis.usgs.gov) were used for LULC classification. The acquisition dates were 13 October 2013 and 29 October 2013 both with path-row 19353. The acquisition dates were chosen since they fit well with the high photosynthetic activity of natural vegetation, crops and offset cloud cover and fire pattern disturbance. The scenes selected had zero percent cloud cover. Landsat 8 images were provided atmospherically and geometrically corrected (Landsat 8 , level 2A product).

To separate agroforestry and plantation which are easily confused with natural vegetation at the $30 \mathrm{~m}$ Landsat resolution we used Worldview- 2 imagery ${ }^{1}(0.46 / 1.84 \mathrm{~m}$ resolution panchromatic/multispectral) from with additional ground truthing data (field surveys of plots data from agroforestry systems and plantations).

\section{Establishment of gridded vegetation index map using MODIS data}

To select sample points that cover the different land use classes adequately, we first derived clusters of land use based on time series of the moderate-resolution imaging spectro-radiometer (MODIS) normalized difference vegetation index (NDVI) product. These clusters were then used as strata in a stratified sampling procedure to select sampling points.

${ }^{1}$ Worldview-2 imagery can be found at http://www.digitalglobe.com.
The NDVI [87] is one of the most widely used vegetation indexes and is correlated with several biophysical properties of the vegetation canopy, such as leaf area index, fractional vegetation cover, vegetation condition, and biomass. The NDVI is defined base on the relationship between near infrared (NIR) and red light (RED) and relates the difference of both wave lengths to their sum (Eq. 1). It is built on the observation that chlorophylls $\mathrm{a}$ and $\mathrm{b}$ in green leaves strongly absorb light in the Red while the cell walls strongly scatter light in the NIR region [88]. NDVI normalizes values between -1 and +1 ; dense vegetation has a high NDVI, while soil values are low but positive, and water is negative due to its strong absorption of NIR.

We used MODIS data with $500 \mathrm{~m}$ resolution and 0 \% cloud cover from August 2013 to November 2013 (https://lpdaac.usgs.gov/products/modis_products table). We calculated the mean NDVI (Eq. 2) of six times series per pixel across time. The mean NDVI was used as input in a k-mean cluster analysis [89] with the number of clusters set to the number of LUCa (forest land, grassland, cropland and settlements and other land use) used in the analysis. The clusters were then used for a stratified random sample creation in ArcGIS 10.2.1. The centroids of the selected pixels were used to establish plots at which ground training area information was derived for the classification (Figs. 1, 2).

$$
\begin{aligned}
& \mathrm{NDVI}_{i}=\frac{\mathrm{NIR}_{i}-\operatorname{Red}_{i}}{\mathrm{NIR}_{i}+\operatorname{Red}_{i}} \\
& \operatorname{Mean}_{\mathrm{NDVI}_{i}}=\frac{\sum_{i=1}^{N}\left(N D V I_{(x, y)} i\right)}{N} \\
& \text { standardized Mean }_{\mathrm{NDVI}_{\mathrm{i}}} \\
& \quad=\left[\left(\text { Mean }_{\mathrm{NDVI}_{\mathrm{i}}}-\mathrm{NDVI}_{\text {min }}\right) /\right. \\
& \left.\quad\left(N D V I_{\text {max }}-N D V I_{\text {min }}\right)\right] \times\left(2^{8}-1\right)
\end{aligned}
$$

where NDVI $=$ normalized difference vegetation index, NIR $=$ near-infrared band of MODIS, Red $=$ red band of MODIS, $i=$ pixel position (i.e. pixel $i$ ) in the scene, $\mathrm{N}=$ number of scenes or elements, $\mathrm{x}=$ longitude coordinate of pixel i, $y=$ latitude coordinate of pixel $i$, Mean $_{\text {NDVI }}(i)=$ mean NDVI of pixel $i$, Min $=$ minimum value of Mean NDVI of all pixels, Max = maximum value of Mean NDVI of all pixels.

We rescaled NDVI from range $[-1 ; 1]$ to $[0 ; 255]$ using the logarithmic function (Eq. 3) in ERDAS Imagine 10 to avoid negative values in data manipulation and visualization (Fig. 2).

Both sample points for calibration as well as for validation were sampled using the same procedure. Validation 


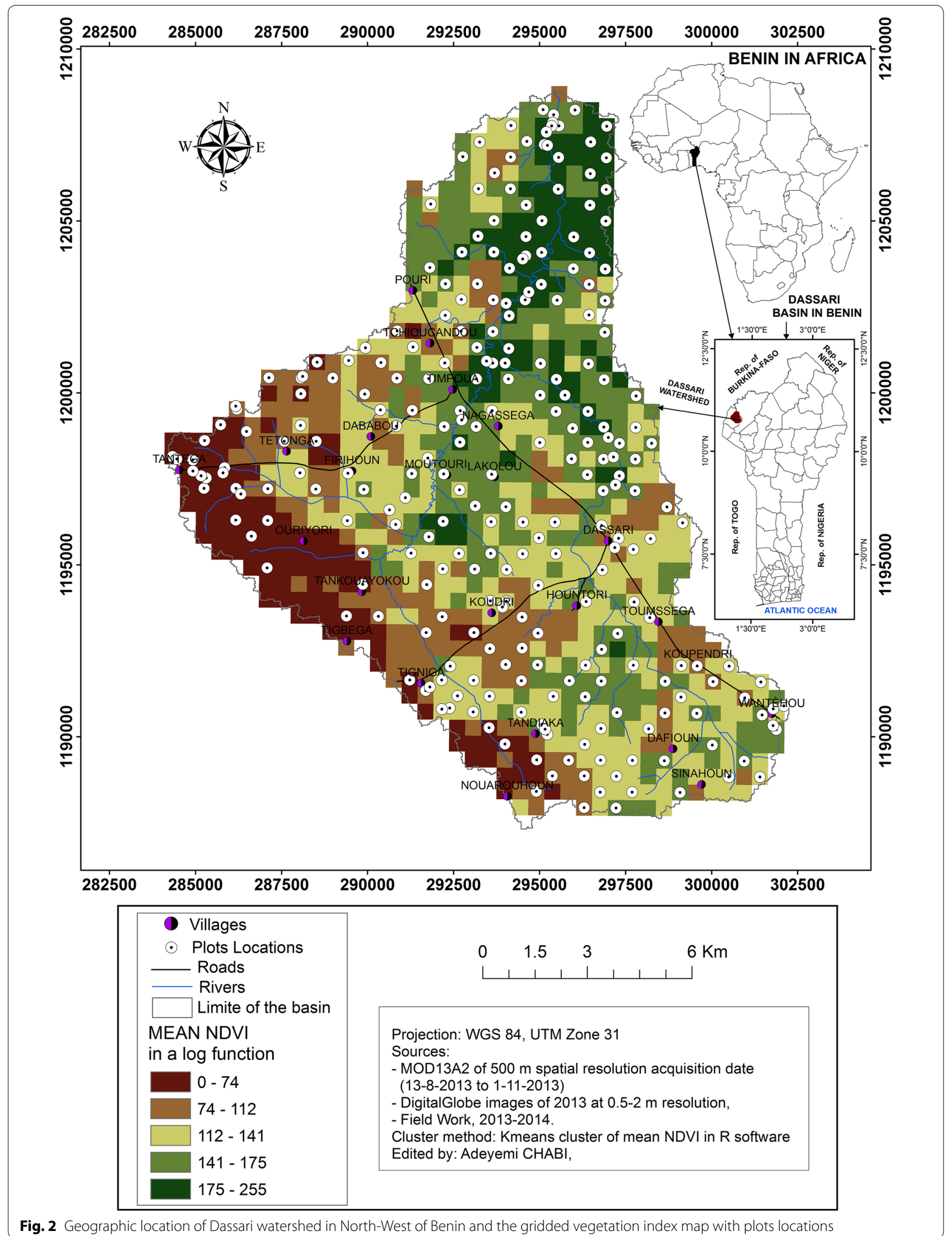


sample points were not used for the training of the classifier.

\section{Image classification}

We used seven LULC classes that reflect the dominant land use classes for biomass stocks assessment in our case study region: riparian forest and woodland, Savanna Woodland, shrub savanna, cropland and fallow, settlements, agroforestry and plantation. At some locations in the text we refer to forest land that incorporates the land use category (LUCa) riparian forest and woodland, Savanna Woodland and shrub savanna. We further separated agroforestry and plantation from cropland since an increase of agroforestry and plantation could be a mitigation strategy to climate change.

Based on the ground truthing data derived for the sample points, a random forest classifier was trained and used to classify the Landsat 8 data. For the classification bands 2, 3 and 4 were used. The random forest approach is a machine-learning approach that builds on classification and regression trees but overcomes their sensitivity towards noise in the data. Instead of relying on a single decision tree, using the majority vote of a forest of decision trees fit to bootstrap samples from the original data. While individual decision trees suffer from a high variance of estimates the averaging across the bootstrap sample leads to a significant variance reduction [90, 91]. In addition to bagging approaches, random forests decorrelate the trees by using only a random sample of the variables (i.e. spectral bands) for each split. The analysis was done in $\mathrm{R}$ [69] using the package randomForest [70]. Random forest classifiers have been applied successfully in a number of remote sensing studies [92-94] which showed that the approach is superior to the widely used maximum likelihood classifier.

Since it was not possible to separate agroforestry and plantations from forest land at the scale of the Landsat 8 data these classes were separated based on several high resolution Worldview-2 images, known plantation and agroforestry sites and their geometric properties (regular spacing between trees) in ArcGIS 10.2.1. Areas that were identified as either agroforestry or plantation were validated in the field and assigned to the proper class based on the field validation. For the final LULC map identified agroforestry and plantations were superimposed on the existing classification (Fig. 1).

\section{Accuracy assessment of the classification}

The accuracy of the random forest classification (without the superimposed classification of agroforestry and plantations) was based on independent validation points that were sampled similar to the training sample points. By comparing classification results and observed land use classes at the location of the validation points a confusion matrix was derived. Based on the confusion matrix overall accuracy and the kappa index [71] were derived to assess the accuracy of the classification.

\section{Forest inventory}

Forest inventory and tree species community analysis was carried out during 7 months (from March to September 2014). In every LULC class, plots were installed randomly proportionally to their size (Table 1 ) using the equation from Pearson et al. [72]. The size of plots was $30 \times 30 \mathrm{~m}$ in forest land, grassland and cropland, $100 \mathrm{~m} \times 100 \mathrm{~m}$ within the settlements and $10 \mathrm{~m} \times 20 \mathrm{~m}$ in agroforestry and plantation. The total 250 plots (Fig. 2; Table 1) have been surveyed which cover 27.26 ha.

\section{Importance value index (IVI) analysis}

The objective of IVI calculation was the selection of the main species of the watershed for the development of tree biomass allometric equations. The IVI analysis has been used for the first time by Curtis [73] to determine the overall importance of tree species for a tree community structure. The IVI of a species is the sum of the

Table 1 Land use/land cover (LULC) classes and number of installed plots

\begin{tabular}{|c|c|c|c|c|c|c|c|c|}
\hline \multirow{3}{*}{$\begin{array}{l}\text { Characteristics } \\
\text { LULC }\end{array}$} & \multicolumn{8}{|c|}{ IPCC [95] land use categories (LUCa) } \\
\hline & \multicolumn{3}{|c|}{ Forestland } & \multirow{2}{*}{$\begin{array}{l}\text { Grassland } \\
\text { GL }\end{array}$} & \multirow{2}{*}{$\begin{array}{l}\text { Cropland } \\
\text { CPF }\end{array}$} & \multirow{2}{*}{$\begin{array}{l}\text { Settlement } \\
\text { SL }\end{array}$} & \multicolumn{2}{|c|}{$\begin{array}{l}\text { Others land } \\
\text { use }\end{array}$} \\
\hline & RFW & sw & SS & & & & AGF & PLT \\
\hline Area (ha) & 341.19 & 5476.5 & 4282.56 & 96.57 & 8044.47 & 488.34 & 20.7 & 17.1 \\
\hline Percentage in the watershed & 1.77 & 28.44 & 22.24 & 0.50 & 41.77 & 2.54 & 0.11 & 0.09 \\
\hline Area sampled (ha) & 0.81 & 2.43 & 5.04 & 3.06 & 7.2 & 8 & 0.26 & 0.46 \\
\hline Number of establishing plots & 09 & 27 & 56 & 34 & 80 & 08 & 13 & 23 \\
\hline
\end{tabular}

Agroforestry and plantation were seen as mitigation strategies to climate change, we therefore choose to discriminate them from cropland

RFW riparian forest and woodland, SW Savanna woodland, SS shrub Savanna, GL grassland, CPF cropland and fallow, SL settlement, AGF agroforestry, PLT plantation 
relative frequency, relative density and relative dominance of the species in a region.

Relative density (RD\%) for species i:

$$
R D_{i}=\frac{\text { Density of species } A i}{\text { Total density for all species }} \times 100
$$

Relative frequency (RF\%) for species i:

$$
R F_{i}=\frac{\text { Frequency value for species } A i}{\text { Total frequency values for all species }} \times 100
$$

Relative dominance (RDom\%) for species i:

$$
R_{\text {Dom }}=\frac{\text { Dominance for species Ai }}{\text { Total dominance for all species }} \times 100
$$

Importance value index (IVI):

$$
I V I\left(A_{i}\right)=R D_{i}+R F_{i}+R D_{o m}
$$

where IVI $(\mathrm{A} i)=$ importance value index of species A $i$ with $i$ varied from 1 to $\mathrm{N}$ (here $\mathrm{N}=81$ species), $R D_{i}=$ relative density of species $i(\%), R F_{i}=$ relative frequency of species $\mathrm{i}(\%), \mathrm{RDom}_{\mathrm{i}}=$ relative dominance of species i (\%), Total density for all species = sum of density across all species, Total frequency values for all species $=$ Sum of frequency across all species, Total dominance for all species $=$ sum of dominance across all species.

Among the 84 inventoried species within the entire watershed, only three were not taken into the account for IVI calculation. The first species was Adansonia digitata which has DBH range $9.2-185 \mathrm{~cm}$, with a relative abundance of $9.87 \%$ and the density of $0.54\left(<1\right.$ plant ha $\left.^{-1}\right)$. Phoenix reclinata and Borassus flabellifer were removed since we could rely on published allometric equations for coconut biomass estimation, by Schoroth et al. [74] for these two species. For the remaining 81 species the IVI was calculated using Eqs. 4-7 to obtain 15 most important tree species. These 15 tree species were used for the further analysis.

\section{Field campaign and the estimation of wood density of the main species of the watershed}

The materials used for this study were an increment borer, scale weight of $25 \mathrm{~kg}$, metric tape scaling, metre increment and an oven for drying the wood samples. During the second field campaign (from October 2014 to December 2014) wood samples from 270 trees within the 15 main species (Terminalia macroptera, Acacia seyal, Combretum glutinosum, Pterocarpus erinaceus, Anogeisus leiocarpus, Mitragyna inermis, Lannea microcrapa, Lannea acida, Ficus sp., Crosopteryx febrifuga, Entada africana, Parkia biglobosa, Vitelaria paradoxa,
Azadirachta indica, Anacardium occidentale) were extracted with the increment borer at $1.3 \mathrm{~m}$ above the ground. A. occidentale was surveyed in the agroforestry system (cashew). The basic wood density of the samples was estimated after oven-drying them at $75{ }^{\circ} \mathrm{C}$-over 2-3 days depending on the water content of the wood samples.

\section{Tree measurements (destructive and non-destructive methods)}

It was possible to analyse trees selected for logging in a rural electrification project along the road from DassariTigniga (Fig. 2) in the Dassari basin. Seven species ( $T$. macroptera, Ficus sp., A. seyal, Entanda Africana, C. glutinosum, C. febrifuga and A. leiocarpus) and 13 individual trees were selected. Only tree species which were going to be logged by rural electrification project officers and that belonged to the previously mentioned 15 main species (Table 3) of the watershed were analysed. These samples allowed the estimation of the parameters of the BEF function as well as an assessment of the uncertainties attached.

The following activities were undertaken in preparation for the use of the non-destructive approach:

1. Measurement of stem girth at $1.3 \mathrm{~m}, 2.3 \mathrm{~m}$ and crown base, and stem height (Fig. 3);

2. Extraction of stem wood sample of the tree at $1.3 \mathrm{~m}$ above ground using the increment borer;

3. Oven-drying the wood sample obtained with the increment borer and estimation of the wood density of the surveyed tree;

4. Estimation of stem-dry mass of the tree species using Eqs. 8-11.

The destructive approach consisted of the following steps:

1. Logging of the tree species by rural electrification project officers,

2. Weighting of fresh mass of stem, branches and foliage using scale weighting of $25 \mathrm{~kg}$,

3. Oven-drying of fresh wood samples selected from stem, branches and foliage at $75{ }^{\circ} \mathrm{C}$ for $2-3$ days to constant weight;

4. Estimation of dry mass of stem, branches and foliage of the tree using Eq. 12,

5. Calculation of BEF based on dry mass of stem, branches and foliage using Eq. 13,

6. Modelling BEF as a function of stem dry mass using Eq. 14, 


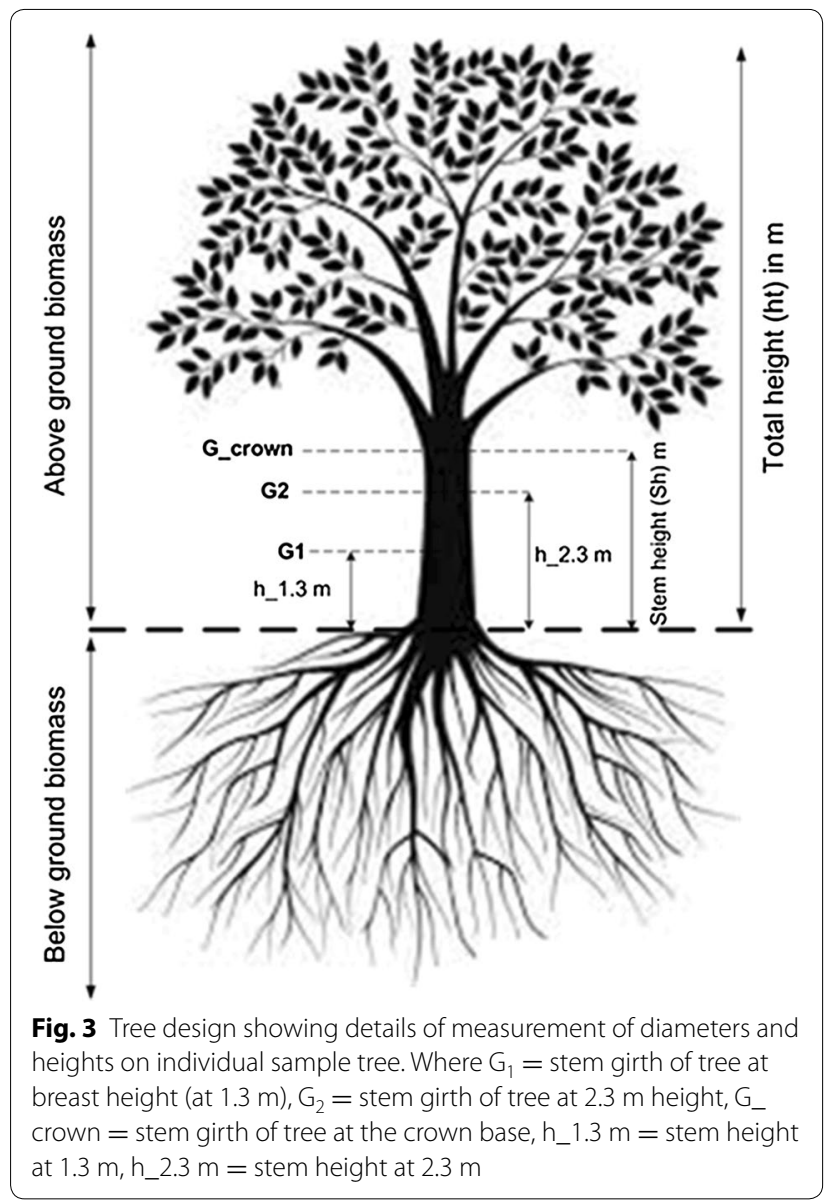

7. Comparison of the non-destructive method to the destructive method based on predictive total biomass by BEF function.

Figure 3 shows the various properties collected from sample trees in this watershed.

The pole of tree height measurement was $4 \mathrm{~m}$ in length. One worker holds the pole next to the tree when measuring the stem height. The second worker stood far enough away to estimate the stem height of the tree. Samples of wood were extracted from the tree using an increment borer (Fig. 4).

\section{Collection of wood samples in the field}

The inner diameter of the bit of the increment borer device was $0.5 \mathrm{~cm}$ leading to a diameter of the sample of $0.5 \mathrm{~cm}$. The length $\mathrm{L}$ of the sample was measured after its extraction. The application of the tool is shown in Fig. 4.

The main activities preformed related to the destructive approach were the estimation of dry mass of wood samples of stem, branches and foliage followed by the estimation of BEF.

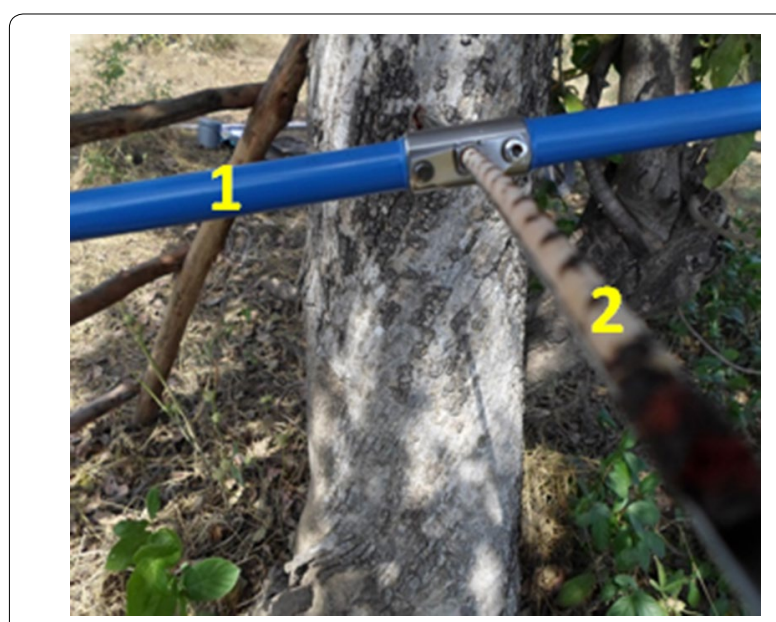

Fig. 4 Wood sample obtained from increment borer. CHABI, October 2014. 1 Increment borer, 2 wood sample

\section{Data analysis}

\section{Estimation of basic wood density}

The core wood sample was oven-dried at $75{ }^{\circ} \mathrm{C}$ during 2-3 days till the stabilization of dry mass. The oven dry density $(\rho)$ in terms of dry mass per fresh volume $\left(\mathrm{g} \mathrm{cm}^{-3}\right)$ of all collected wood samples was estimated using Eq. 8.

$$
\rho=\frac{4 \mathrm{dMS} \mathrm{S}_{\mathrm{i}}}{\pi d^{2} L_{i}}
$$

where: $\mathrm{dMS}_{\mathrm{i}}=$ dry mass of wood sample i obtained by the increment borer, $d=$ diameter of the bit, $L_{i}=$ length of the sample i.

\section{Estimation of stem volume and stem biomass of surveyed trees}

The stem volume of the trees was measured by section according to Fig. 3. The truncated cone function was used to estimate this stem volume (Eq. 9):

$$
\text { Vistem }_{i}=\mathrm{H}_{\mathrm{i}} \times \frac{1}{12 \pi} \times\left(C_{1 i}^{2}+C_{2 i}^{2}+C_{1 i} \cdot C_{2 i}\right)
$$

where $\mathrm{H}_{\mathrm{i}}=$ height in $\mathrm{m}$ of section $\mathrm{i}$ of the tree stem, $\mathrm{C}_{1 \mathrm{i}}=$ the greater girth of the section $\mathrm{i}$ of the tree stem, $\mathrm{C}_{2 \mathrm{i}}=$ the smaller girth of the section $\mathrm{i}$ of tree stem, Vistem $_{\mathrm{i}}=$ Volume in $\mathrm{cm}^{3}$ of section $\mathrm{i}$ of the tree stem.

The stem biomass was estimated based on wood density and stem volume values of the sections of the tree stem (Eq. 10) and added up to get the total stem biomass based on non-destructive approach (Eq. 11):

$$
\begin{aligned}
\text { Bistem }_{i} & =\left(\rho \times \text { Vistem }_{i}\right) / 1000 \\
\text { TBstem } & =\sum_{i=1}^{n} \text { Bistem }_{i}
\end{aligned}
$$


where Vistem $\mathrm{i}_{\mathrm{i}}=$ volume in $\mathrm{cm}^{3}$ of section $\mathrm{i}$ of the tree stem, Bistem $_{\mathrm{i}}=$ biomass in $\mathrm{kg}$ of section $\mathrm{i}$ of the tree stem, TBstem $=$ total biomass of tree stem, $\mathrm{n}=$ number of the section of the tree stem.

In the next step, dry mass of stem, branches and foliage were added up to get the total biomass of the tree based on destructive approach:

$$
\text { Btot }=\sum_{j=1}^{m} \frac{f M_{j} \times d M S_{j}}{f M S_{j}}
$$

where Btot $=$ total biomass of a tree (sum of dry mass of stem, branches and foliage) in $\mathrm{kg}, \mathrm{fM}=$ fresh mass of stem, branches or foliage, dMS = dry mass of wood sample of stem branches or foliage, $\mathrm{fMS}=$ fresh mass of sample of stem branches or foliage, $j=$ index of the different components (stem, branches and foliages), $\mathrm{m}=$ number of components, 3 in the present case.

The BEF per tree was calculated using Eq. 13.

$$
B E F=\frac{\text { Btot }}{\text { Bstem }}
$$

where Btot $=$ total biomass of a tree (sum of dry mass of stem, branches and foliage) in $\mathrm{kg}$, Bstem $=$ stem dry biomass in $\mathrm{kg}, \mathrm{BEF}=$ biomass expansion factor.

\section{Modelling BEF as a function of stem dry mass}

The relationship between BEF and stem dry biomass (Bstem) was modelled by a linear regression model in $\mathrm{R}$ [75]. Stem dry biomass has been log-transformed to provide a more even spread of the data.

$$
\mathrm{BEF}=\beta_{0}+\beta_{1} \ln (\text { Bstem })+\varepsilon
$$

where $\beta_{0}$ and $\beta_{1}$ are regression coefficients and $\varepsilon$ the error term which we assume to be normally distributed and centred on zero.

\section{Fitting aboveground biomass ( $A G B$ ) equations for the surveyed individual tree species}

Total samples consisted of 270 individual trees that have been non-destructively surveyed (Table 3 ). For each tree of that sample, the BEF was applied to calculate the AGB. This AGB was then modelled by generalized linear models (GLM) [76] using predictors easily measured in the field. We selected DBH, total height $(\mathrm{H})$ and wood density $(\rho)$ as predictors. Since the effort to measure the predictors increases from DBH to $H$ and to $\rho$ we fitted models for three sets of predictors: (1) just on $\mathrm{DBH}$, (2) DBH and $\mathrm{H}$, (3) all three predictors together. Based on the properties of the residuals we decided on a Gamma GLM with a log link. For each level of complexity we started with a model that contained the interactions between all involved predictors as well as the main effects (conditional on the interactions). We tried to simplify the model structure based on the small sample size of corrected Aikaike information criteria (AICc) [77, 78]. Quadratic effects were not considered since their inclusion led to unrealistic model behaviour for higher response values which we interpreted as a result of overfitting the model.

The aim was the fitting of model at land use categories (LUCa) level-i.e. data were subsetted by LUCa before fitting-in addition to a generic category which included all LUCas. Effects of species on the model fit as well as on the structure of the residuals were tested but effects were small. We used the following LUCa to fit the models: forest land (the combination of riparian forest, Savanna Woodland and shrub savanna), savanna grassland (grassland), settlement, cropland (cropland and fallow). The sample size differed by LUCa: agroforestry: 25, forest: 181, cropland: 178 , settlements: 63 , grassland: 90 . We did not fit models for the LUCa plantation but applied published equations. AGB from plots plantations of Tectona grandis and Eucalyptus grandis were obtained using respectively published allometric equations from Guendehou et al. [42] and Montagu et al. [79] whereas the generic equation (cf. Fig. 7; Additional file 2) was applied to estimate AGB of $A$. indica and Gmelina arborea.

\section{Validity domain of equations for $D B H$}

The models were run under certain ranges of $\mathrm{DBH}$ obtained from each LUCa. The DBH ranges were 5.6$44.7,7.6-40.7,6.9-62.4,7-52.7$ and $9.2-57.9 \mathrm{~cm}$ respectively in forest land, savanna grassland, cropland and fallow, settlement and agroforestry systems (cashew plantation).

\section{Estimating aboveground biomass at the watershed level}

We generated the biomass density map using the best specific equation for each LUCa especially equation type III which involved the three predictors. For agroforestry model II was used since wood density did not have a significant effect on AGB estimates in this LUCa. We estimated biomass content of each plot in two steps when we found $P$. reclinata and $B$. flabellifer in the plot data. We first retrieved these species from each plot data and we estimated their biomass using equation from Schoroth et al. [74] developed for the estimation of AGB of coconut. In the second step we applied specific equations for the concerned plots and we summed up together the two results to obtain the total biomass of the plot. The total biomass stocks of each LULC class is equal to the mean AGB density expressed in $\mathrm{Mg} \mathrm{ha}^{-1}$ times the area in ha of the defined LULC class. The biomass stocks map was edited using ArcGIS 10.2.1 software. 


\section{Results and discussion}

\section{Land use classification}

The accuracy of the classification of the Landsat 8 imagery (Fig. 5) was acceptable to good given the overall accuracy of 0.75 and the kappa index of 0.70 . Since the identification of the agroforestry systems and plantations was done manually we could not derive an accuracy measure.

\section{Main species in the study area}

Based on the IVI analysis we identified 15 main species that were used for the further analysis. These represented $80.5,82.75,79.55$ and $76.8 \%$ of the total number of tree species for forest land, grassland, cropland and fallow, and settlement respectively (cf. Table 2).

\section{Basic wood density of the main species of the study area}

Table 3 shows the estimated basic wood density of the main species in the study area. The species $A$. leiocarpus, C. glutinosum, T. macroptera, V. paradoxa, P. erinaceus, $A$. indica, A. seyal, and C. febrifuga were characterized by a high mean wood density. The low mean density observed for L. microcrapa and Ficus sp. is in line with the high water content of the species which is lost during the drying process. Standard deviations of the measurements were very low for all species and confirmed

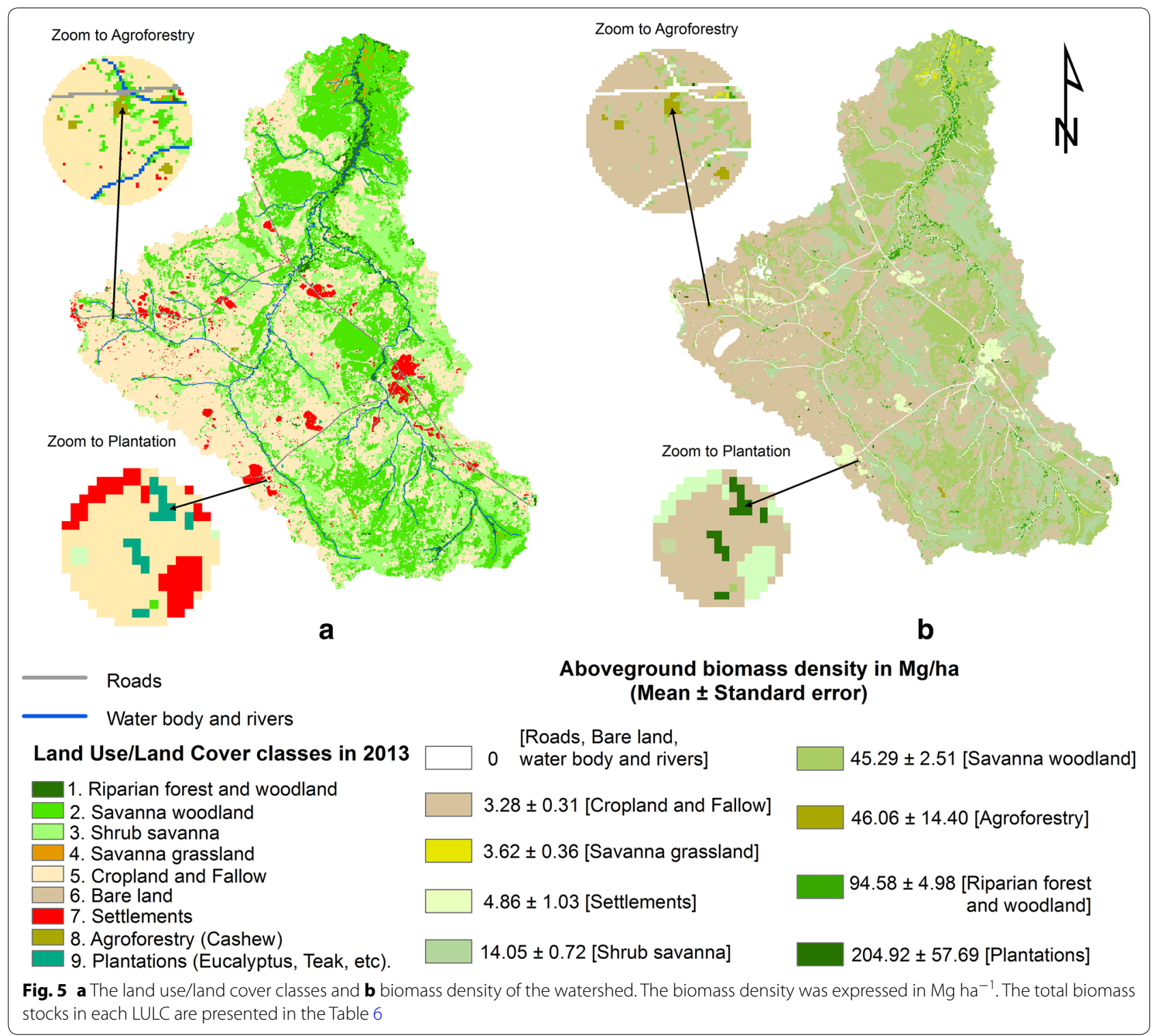


Table 2 Importance value index of main species in each land use/cover category (LUCa)

\begin{tabular}{lllll}
\hline Species name & \multicolumn{4}{l}{ Importance value index (IVI) (\%) } \\
\cline { 2 - 5 } & Forestland & Grassland & Cropland & Settlement \\
\hline T. macroptera & 42.57 & 125.85 & 19.23 & - \\
A. seyal & 33.18 & 24.39 & 21.01 & - \\
C. glutinosum & 31.13 & - & 5.99 & - \\
P. erinaceus & 25.55 & - & 6.02 & - \\
A. leiocarpus & 24.09 & - & - & - \\
M. inermis & 18.22 & - & - & - \\
L. microcrapa & 16.06 & - & 44.97 & 28.25 \\
Ficus sp. & 8.79 & 32.28 & 28.84 & 42.08 \\
C. febrifuga & 8.01 & - & - & - \\
E. africana & 7.32 & 22.27 & - & - \\
P. biglobosa & - & 42.14 & 65.50 & - \\
V.paradoxa & - & - & 21.28 & - \\
A. indica & - & - & 15.92 & 96.63 \\
\hline
\end{tabular}

thereby the accuracy of the measurements as well as the relative low importance of confounding factors which influence density variation per species as described by Chave et al. [56]. Measurements on basic wood density were in line with results from previous studies [57-62].
BEF

The BEF increased significantly with the log of stem dry biomass (Table 4; Fig. 6, left panel). The BEF as a function of stem dry biomass varied between 1.46 and 1.88 with a mean of $1.67 \pm 0.04$ (SE). The BEF of T. macroptera which is the main species of the study site ranged from 1.55 to 1.88 with a mean of $1.73 \pm 0.009$ (SE). The model explained $69 \%$ of the variance in the data. Residuals showed no relevant pattern with respect to the different tree species.

Total biomass obtained by the destructive method (observed values from 13 trees) and the total biomasses estimated by the non-destructive method (predicted values from these trees using the estimated $\mathrm{BEF}-$ stem dry mass relationship) were highly similar (Fig. 6 centre panel, Pearson correlation coefficient of 0.99).

Our results differ significantly from relationships identified in other land systems stressing the importance of deriving BEF relationships adjusted to the conditions in the ecozone. Segura [63] used a similar approach based on an estimated BEF function for the per-humid premontane transitional forest zone in Costa Rica. In contrast to our findings BEF decreased with stem biomass in Costa Rica. While the Costa Rican study underestimated total biomass of trees on average by $17.31 \%$, the application of the BEF to our data overestimated total biomass slightly

Table 3 The basic wood density $\left(\mathrm{g} \mathrm{cm}^{-3}\right)$ of the main species of the watershed

\begin{tabular}{|c|c|c|c|c|c|c|c|}
\hline \multirow[t]{3}{*}{ Trees species } & \multicolumn{6}{|c|}{ The present study } & \multirow{3}{*}{$\begin{array}{l}\text { Previous studies } \\
\rho\left(\mathrm{g} \mathrm{cm}^{-3}\right)\end{array}$} \\
\hline & \multirow[t]{2}{*}{$n$} & \multicolumn{2}{|c|}{ Basic wood density } & \multirow[t]{2}{*}{ Mean (SE) } & \multicolumn{2}{|c|}{$\mathrm{DBH}(\mathrm{cm})$} & \\
\hline & & Min. & Max. & & Min. & Max. & \\
\hline T. macroptera & 19 & 0.740 & 0.893 & $0.821(0.010)$ & 9.3 & 40.7 & $0.768^{\mathrm{a}} ; 0.870^{\mathrm{b}}$ \\
\hline A. seyal & 16 & 0.669 & 0.909 & $0.751(0.015)$ & 7.6 & 34.4 & - \\
\hline C.glutinosum & 11 & 0.827 & 0.962 & $0.877(0.013)$ & 7.9 & 31.9 & $0.900^{b}$ \\
\hline P. erinaceus & 21 & 0.671 & 0.973 & $0.826(0.015)$ & 6.9 & 44.7 & $0.740^{a}$ \\
\hline A. leiocarpus & 16 & 0.813 & 0.977 & $0.889(0.012)$ & 6.9 & 32.4 & - \\
\hline M. inermis & 18 & 0.579 & 0.687 & $0.631(0.008)$ & 7.0 & 34.5 & - \\
\hline L. microcrapa & 22 & 0.472 & 0.648 & $0.546(0.011)$ & 7.0 & 50.6 & - \\
\hline L. acida & 06 & 0.504 & 0.676 & $0.573(0.027)$ & 10.8 & 35.9 & - \\
\hline Ficus sp. & 21 & 0.440 & 0.607 & $0.528(0.010)$ & 8.6 & 52.7 & - \\
\hline C.febrifuga & 18 & 0.518 & 0.778 & $0.704(0.016)$ & 5.6 & 30.5 & - \\
\hline E. africana & 15 & 0.556 & 0.688 & $0.631(0.010)$ & 8.4 & 27.6 & - \\
\hline P. biglobosa & 23 & 0.566 & 0.689 & $0.630(0.006)$ & 8.6 & 62.4 & $0.525^{c}$ \\
\hline V.paradoxa & 23 & 0.608 & 0.950 & $0.838(0.016)$ & 8.0 & 53.8 & - \\
\hline A. indica & 16 & 0.619 & 0.886 & $0.763(0.018)$ & 8.8 & 50.5 & $0.660^{d} ; 0.620^{e}$ \\
\hline A. occidentale & 25 & 0.512 & 0.625 & $0.569(0.006)$ & 9.2 & 57.9 & $0.431^{c} ; 0.500^{e}$ \\
\hline
\end{tabular}

$\mathrm{n}=$ Number of tree selected. The stem wood samples of selected trees were extracted at $1.3 \mathrm{~m}$ of the ground. DBH range $=$ range of diameter at breast height of sampled tree species. Figures in bracket represent the standard error (SE) of the mean

Authors of previous studies: ${ }^{a}$ Sallenave [57, 58], ${ }^{\text {b }}$ Von Maydell [59], ${ }^{\mathrm{C}}$ Carsan et al. [60], ${ }^{\mathrm{d}}$ Oey et al. [61], ${ }^{\mathrm{e}}$ Little et al. [62] 
Table 4 Coefficients for the BEF-stem dry biomass relationship and for the BEF-DBH relationship fitted

\begin{tabular}{lcll}
\hline & Coefficient & SE & p value \\
\hline $\begin{array}{l}\text { BEF-stem dry biomass relationship } \\
\text { Intercept }\end{array}$ & 1.24155 & 0.09253 & $3.66 \times 10^{-8}$ \\
In(stem dry biomass) & 0.14701 & 0.02968 & 0.000434 \\
BEF-DBH relationship & & & \\
Intercept & 1.25801 & 0.07697 & $4.61 \times 10^{-9}$ \\
DBH & 0.0314 & 0.00543 & 0.000122 \\
\hline
\end{tabular}

Both regressions were fitted based on the 13 trees available for the destructive method and non-destructive assessment

by $1.82 \%$. Levy et al. [64] estimated the biomass expansion of coniferous species in Great Britain as a function of tree height of stand tree. An application of Levy's BEF to our data overestimated the total biomass of our sampled tree species to on average by $4.46 \%$. Magalhães and Seifert [65] used BEF as a function of DBH when estimating AGB of Androstachysjohnsonii Prain in Mozambique. The application of the BEF of Magalhães and Seifert [65] to our data underestimated the total biomass of our sampled tree species on average by $62.54 \%$.

Given the small sample size (13 individual trees within seven species) and the limited range of DBH $(<25 \mathrm{~cm})$ care should be taken not to extrapolate results. However, the sampled trees represent the common size distribution of trees in the human influenced ecosystems of the study region. Therefore, our results can be assumed to provide a good estimate for BEF assessments in the region.

Alternatively, BEF could be estimated based on DBH of the 13 trees assessed by the destructive approach (Fig. 6, right panel).The model based on DBH was slightly superior to the model based on stem dry biomass if compared by means of the small sample size corrected AIC (AICc) or a likelihood ratio test and it explained $75 \%$ of the variance in the BEF (Table 4).

If this model was used to predict total biomass, the values derived by the destructive approach were overestimated on average by $2.27 \%$-a bit higher compared to the model based on stem dry mass. We therefore stuck to the estimation based on stem dry biomass.

\section{Aboveground biomass (AGB) models at the watershed level}

All models indicated a high goodness of fit expressed by the explained deviance as well as by the pseudo- $\mathrm{R}^{2}$ by Nagelkerke [66]. While the AICc clearly favoured the more complex models (cf. Fig. 7 even the models using only DBH as a predictor provided a high goodness of fit. An analysis of the effects of LUCa as an additional predictor on all sample points indicated significant differences between the coefficients across LUCa. This is also visible when comparing regression coefficients per model type across LUCa (cf. Fig. 8). Expectedly, the generic landscape model could not capture this variability. However, inside a model class, coefficients always were of same sign and of the same order of magnitude. For models of type II, the inclusion of the interaction between DBH and total height were always selected based on the lower AICc. For the other categories wood density was included in the models in addition to the other two main effects and the interaction between DBH and total height. For forest land and grassland, the interaction between DBH and wood density was also selected based on AICc. The basic wood density $(\rho)$ was not a good predictor for the estimation of AGB in agroforestry system (cashew plantation). This can be explained by the fact that cashew was the only tree species in that LUCa and that wood density measurements for that species had a relatively
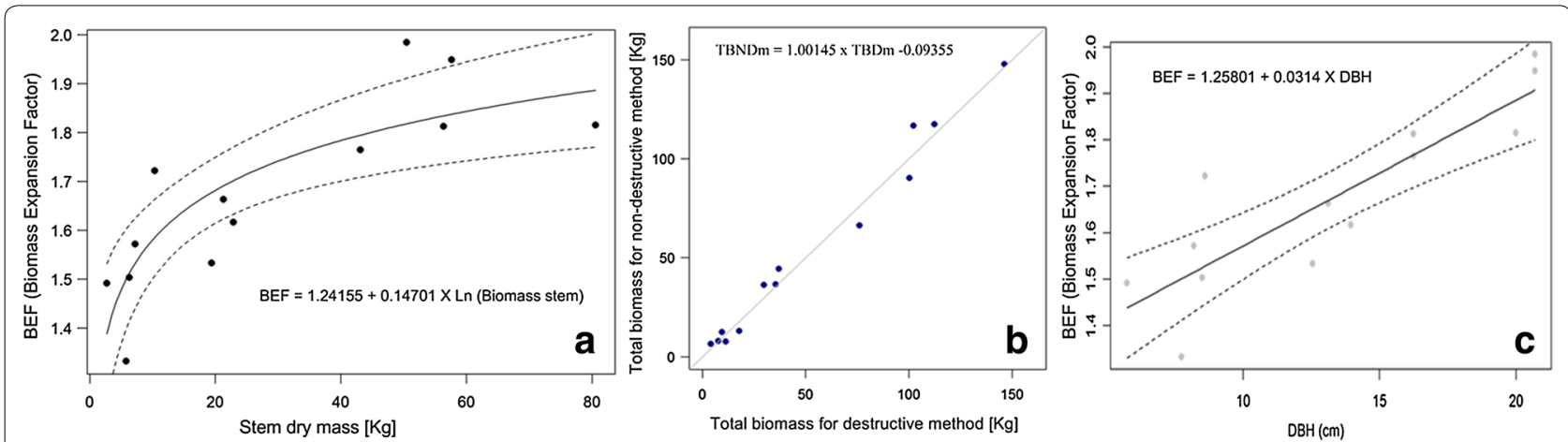

Fig. 6 a Estimated relationship between stem dry biomass and biomass expansion factor modelled for the 13 trees that were available for the analysis by the destructive approach (left panel). The dashed lines represent the $95 \%$ confidence band. b Comparison between total biomass derived by the destructive and the non-destructive method (centre panel). The grey line represents the 1:1 line to aid interpretation. c Estimated relationships between DBH and biomass expansion factor modelled for the 13 trees that were available for the analysis by the destructive approach (right panel). The dashed lines represent the $95 \%$ confidence band 


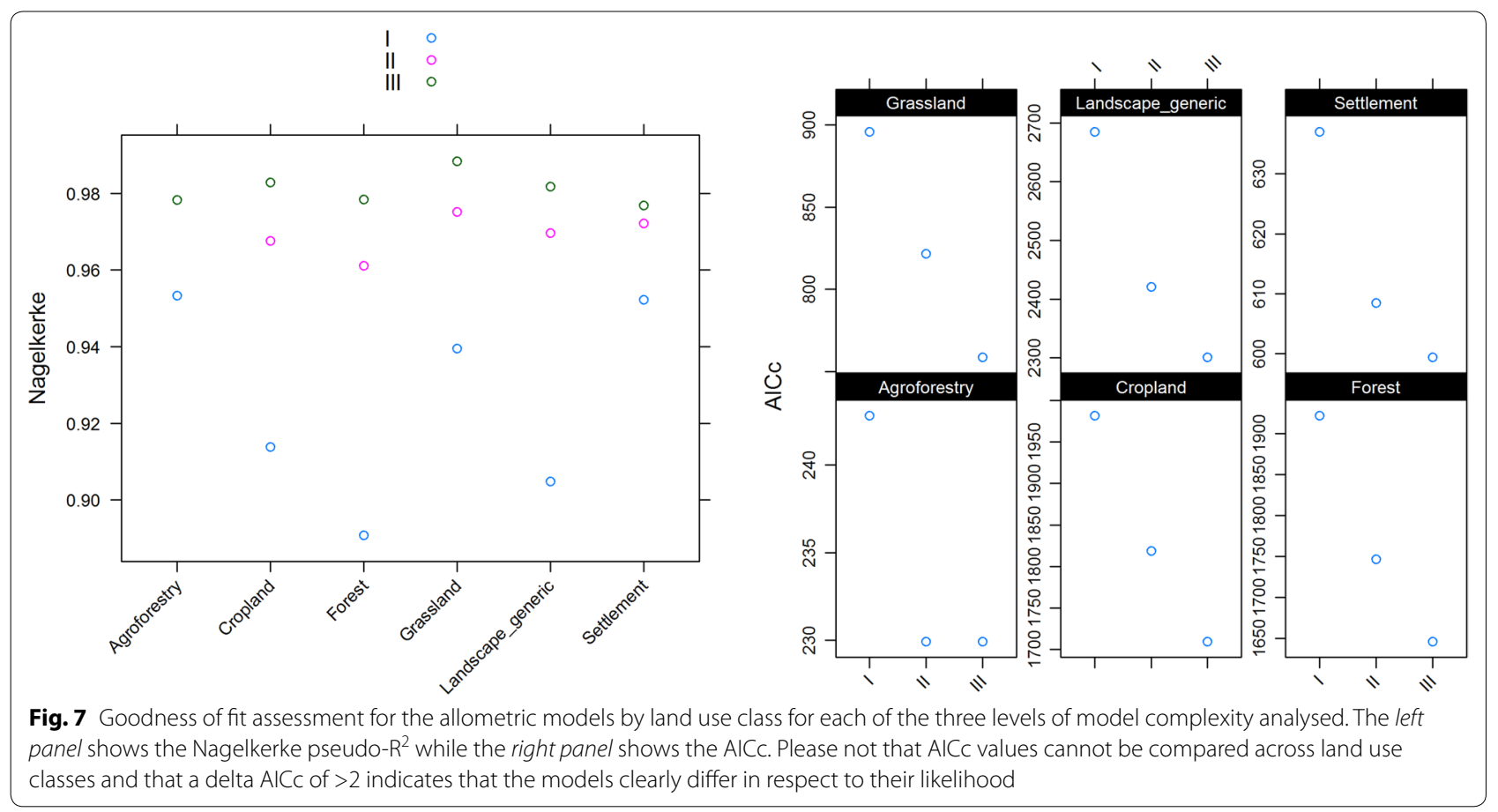

low variance. In cashew plantations big trees-i.e. cashew trees older than 45 years - tend to lose their wood ignition followed by the observed decrease of wood density for bigger cashew trees. In the available 25 cashew trees wood density was high for cashew trees with an age of 10-20 years.

For model type I regression coefficients for DBH differ by around $40 \%$ with lowest estimates for agroforestry and highest values for forests and grasslands. For model II agroforestry and settlements have clearly distinct coefficient estimates from the other land use classes. Model coefficients for model type III are hard to compare since the interaction between wood density and height was only significant for forest and grasslands. Effects plots (cf. Additional file 1) indicated, that the differences between regression coefficients across the LUCa led to important changes in prediction.

\section{Comparing the equations to previously published equations}

We could only compare our allometric models for forest lands with previous published allometric equations due to the lack of allometric equations for cropland, grassland and settlements. We therefore compared only the models for forest land and the generic model with results from Brown [67], Chave et al. [22], Chave et al. [3] and de Jose [45]. We choose equations developed by these authors in the global dry forest region for the comparison. Our results were in line with all mentioned equations in terms of mean deviation of the observed AGB at the stand tree level (Table 5). Our model type I which was only based on DBH differed on average by $21.67 \%$ from the observed AGB for forest land. Results from the equations based on DBH for Brown [67] and de Jose [45] differed on average by 25.02 and $26.41 \%$ respectively. The same analysis was done with the model type II and III in comparison with the previous studies when DBH was not the only predictor. Model type III differed on average by $4.77 \%$ for forest land whereas Chave et al. [22] and Chave et al. [3] respectively differed by 9.04 and $14.78 \%$. This highlights the importance of allometric models adjusted to the regional conditions in the Sudan Savannah ecosystems in West Africa.

\section{Aboveground biomass density and stocks at the watershed level}

The results for biomass density in Savanna Woodland and riparian forest were in the same magnitude with those obtained by Sidzabda et al. [80] in forest land of the Sudan Savannah zone of Burkina-Faso. The mean biomass density and attached standard error varied from $3.28 \pm 0.31$ to $204.92 \pm 57.69 \mathrm{Mg} \mathrm{ha}^{-1}$ across the LUCas (Fig. 5; Table 6) with the lowest biomass density in cropland and the highest biomass density in plantations emphasizing the potential of plantations as a mitigation strategy for the climate change. Biomass density differed however strongly between the different trees used in plantations. High uncertainty of biomass estimates for 


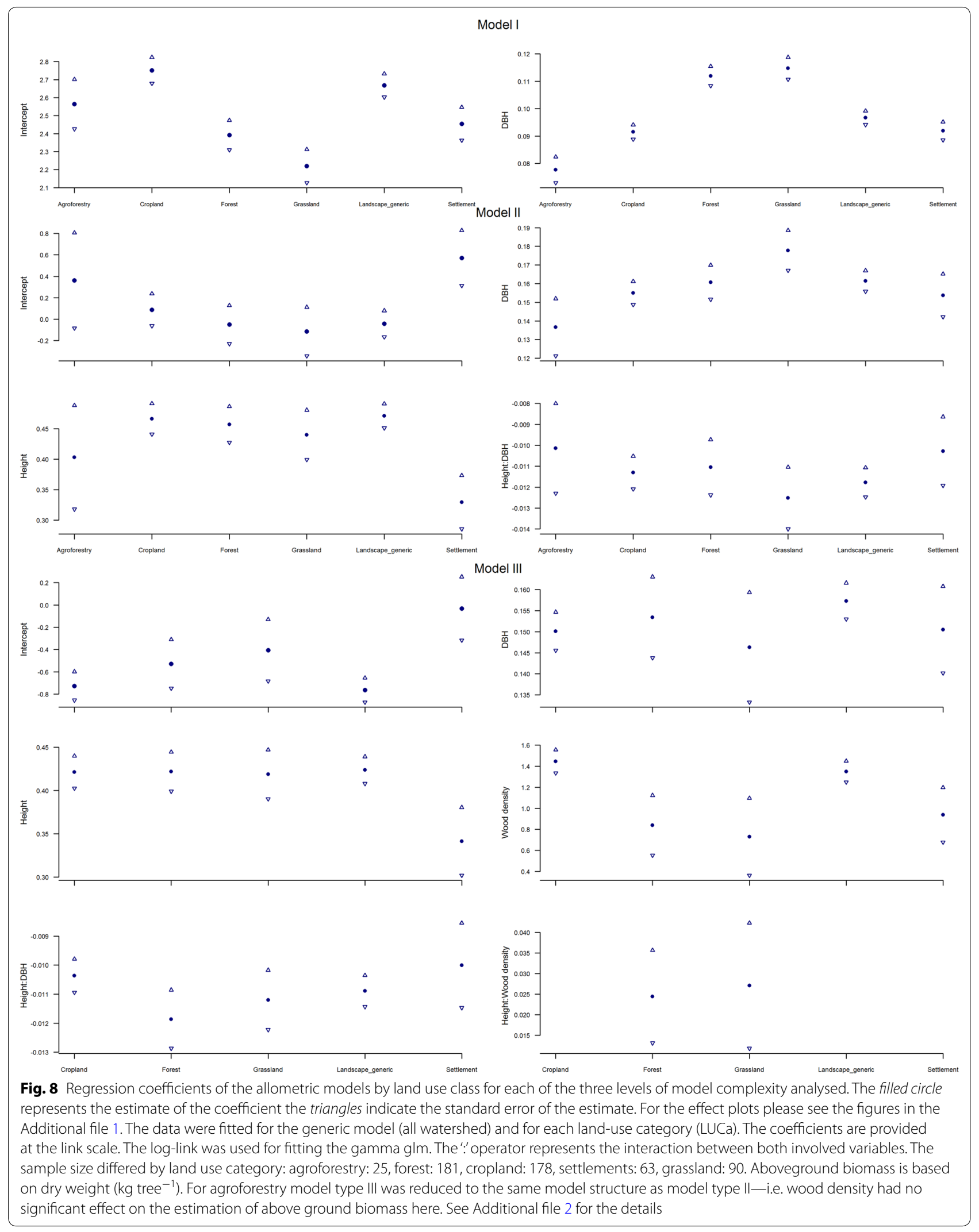


Table 5 The average deviation of various models compared to the models type of the present study in each LUCa

\begin{tabular}{|c|c|c|c|c|c|c|c|}
\hline \multirow[t]{4}{*}{ LUCa } & \multicolumn{4}{|c|}{ Previous studies } & \multirow{2}{*}{\multicolumn{3}{|c|}{$\begin{array}{l}\text { Present study } \\
\text { Models type }\end{array}$}} \\
\hline & \multirow[t]{2}{*}{ Brown [67] } & \multirow[t]{2}{*}{ Chave et al. [22] } & \multirow[t]{2}{*}{ José [45] } & \multirow[t]{2}{*}{ Chave et al. [3] } & & & \\
\hline & & & & & 1 & II & III \\
\hline & \multicolumn{4}{|c|}{ Average deviation $\delta(\%)$} & & & \\
\hline Forest land & 25.02 & 9.04 & 26.41 & 14.87 & 21.67 & 8.64 & 4.77 \\
\hline Grassland & 34.23 & 6.54 & 35.73 & 12.69 & 11.88 & 5.00 & 2.34 \\
\hline Cropland & 29.30 & 10.21 & 30.77 & 14.74 & 24.50 & 10.06 & 5.26 \\
\hline Agroforestry & - & - & - & - & 8.00 & 3.75 & - \\
\hline Settlements & 60.93 & 9.70 & 62.77 & 15.46 & 12.40 & 7.30 & 6.35 \\
\hline Generic & - & 9.00 & - & 14.19 & - & - & 5.34 \\
\hline
\end{tabular}

Table 6 Aboveground biomass density $\left(\mathrm{Mg} \mathrm{ha}^{-1}\right)$ and total biomass stocks $(\mathrm{Mg})$ with the sample plots data and attached uncertainty

\begin{tabular}{|c|c|c|c|c|c|}
\hline \multirow[t]{3}{*}{ LULC/LUCa } & \multicolumn{5}{|c|}{ Descriptive statistic } \\
\hline & \multicolumn{2}{|c|}{$\begin{array}{l}\text { Range of biomass } \\
\text { density }\left(\mathrm{Mg} \mathrm{ha}^{-1}\right)\end{array}$} & \multirow[t]{2}{*}{ Mean biomass density (SE) } & \multirow[t]{2}{*}{$\begin{array}{l}\text { Percentage error } \\
\text { (\% error) }\end{array}$} & \multirow[t]{2}{*}{ Total biomass stocks (Mg) and its SE } \\
\hline & Min. & Max. & & & \\
\hline Forest land & & & & & $340,534.70 \pm 36,445.4$ \\
\hline Riparian forest and woodland & 76.29 & 120.22 & $94.58(4.98)$ & $(10.33)$ & $32,271.87 \pm 334.74$ \\
\hline Savanna Woodland & 27.22 & 69.84 & $45.29(2.51)$ & $(10.89)$ & $24,8050.22 \pm 27,019.98$ \\
\hline Shrub Savanna & 6.47 & 25.14 & $14.05(0.72)$ & $(10.11)$ & $60,212.61 \pm 6090.67$ \\
\hline Grassland & & & & & $349.66 \pm 68.81$ \\
\hline Savanna grassland & 0.06 & 9.20 & $3.62(0.36)$ & $(19.68)$ & $349.66 \pm 68.81$ \\
\hline Cropland & & & & & $26,409.82 \pm 5024.04$ \\
\hline Cropland and fallow & 0.07 & 9.32 & $3.28(0.31)$ & $(19.02)$ & $26,409.82 \pm 5024.04$ \\
\hline Settlements & & & & & $2375.84 \pm 988.13$ \\
\hline Settlements & 0.86 & 9.60 & $4.86(1.03)$ & $(41.59)$ & $2375.84 \pm 988.13$ \\
\hline Agroforestry & & & & & $1132.73 \pm 584.46$ \\
\hline Cashew plantation & 10.74 & 211.19 & $46.06(14.40)$ & $(61.28)$ & $1132.73 \pm 584.46$ \\
\hline Plantation & & & & & $3138.20 \pm 1777.35$ \\
\hline E. grandis & 7.69 & 695.20 & $204.92(57.69)$ & $(55.17)$ & $2819.78 \pm 1556.44$ \\
\hline T. grandis & 32.41 & 232.75 & $162.00(64.88)$ & (78.50) & $145.80 \pm 114.46$ \\
\hline A. indica & 64.45 & 240.53 & $179.62(57.61)$ & $(62.86)$ & $129.33 \pm 81.30$ \\
\hline G. arborea & 10.39 & 34.39 & $25.17(7.46)$ & $(58.09)$ & $43.29 \pm 25.14$ \\
\hline
\end{tabular}

Words in italic indicate the plantation type

Value within the parenthesis indicate the standard error and percentage error

The age of plantations and agroforestry system varied from 5 to 45 years which explained the large standard and percentage errors obtained from their plots data. The minimum ( $\min$.) and maximum (max.), the mean biomass density and its stand error (SE), the percent error and the total biomass at each LULC type/LUCa were illustrated

plantation and agroforestry system might be due to the different age of plots data; since biomass increases with stand age [81]. Since our LULC data classification could not separate between young and old cashew tree plantations we have unfortunately to deal with this high uncertainty. This highlights the need for additional data to assess the potential of agroforestry and plantations as a mitigation strategy to climate change.

The biomass density map (Fig. 5) was generated based on the best model for each LUCa. The map in Fig. 5 shows the LULC types and the biomass density at the watershed level specifically for each LULC class. 
Information on the uncertainties of the biomass density estimation is provided in Table 6.

\section{Conclusion}

The results from this study help to close the existing knowledge gap with respect to biomass estimation in the Sudan Savannah environment. The derived empiric equations fitted to local data should be useful for further work in the Sudan Savannah environment which is characterized by the main species of the present study. The estimation of biomass density and AGB in each LUCa are of great importance for carbon balance calculations in the Sudan Savannah in West Africa. Results include data on wood density of the main species of the Sudan Savannah zone, the related BEF and the biomass density in each LUCa. Our results highlight the importance of model parameters adjusted to the regional conditions in the eco-zone. Plantations and agroforestry system could be a useful mitigation option to battle climate change-however, the differences between the species and the effect of age which could not be satisfyingly handled in our study call for additional research activities. Still, the results provide important information for the carbon accounting programme related to the implementation of the Kyoto Protocol and REDD+ initiatives.

\section{Additional files}

Additional file 1. Effect plots for the allometric models for each LUCa.

Additional file 2. Parameters and expressions of the allometric models generated using diameter at breast height DBH $(\mathrm{cm})$, height $\mathrm{H}(\mathrm{m})$ and wood density $\rho\left(\mathrm{g} \mathrm{cm}^{-3}\right)$.

\section{Abbreviations}

BEF: biomass expansion factor; DBH: diameter at breast height; AGB: aboveground biomass; LULC: land use/land cover; LUCa: land use category.

\section{Authors' contributions \\ AC carried out data collection, designed the methodology and drafted the manuscript. SL performed statistical analysis, provided literature indica- tions and revised the manuscript. VO supervised data collection in the field, provided methodology and revised the manuscript. NKB revised the manuscript and supervised the research. All authors read and approved the final manuscript.}

\section{Authors' information}

AC is the Ph.D. student in Climate Change and Land Use (CCLU) hosted by the Kwame Nkrumah University of Science and Technology. SL is Assistant Professor for Land use Modelling and Ecosystem Services in the University of Bonn at the Institute of Geodesy and Geoinformation. VO is Associate Professor at the University of Abomey-Calavi in Benin. NKB is Professor at Kwame Nkrumah University of Science and Technology in Ghana.

\section{Author details}

${ }^{1}$ Department of Civil Engineering, Kwame Nkrumah University of Science and Technology, Kumasi, Ghana. ${ }^{2}$ Faculty of Agriculture, Institute of Geodesy and Geo-Information, University of Bonn, Nussallee 1, 53115 Bonn, Germany. ${ }^{3}$ Department of Geography, University of Abomey-Calavi, BP 677,
Abomey-Calavi, Benin. ${ }^{4}$ Department of Agricultural Engineering, The College of Engineering, Kwame Nkrumah University of Science and Technology, Kumasi, Ghana. ${ }^{5}$ West African Science Service Centre on Climate Change and Adapted Land Use (WASCAL), Accra, Ghana.

\section{Acknowledgements}

The study is part of Ph.D. thesis in Climate Change and Land Use (CCLU) hosted by the Kwame Nkrumah University of Science and Technology, Kumasi, Ghana. The programme CCLU is under West African Science Service Centre on Climate Change and Adapted Land Use (WASCAL). The authors are most grateful to the German Federal Ministry of Education and Research (BMBF) for sponsoring. We are also grateful to local staff of Dassari basin for their assistance during the field work. Finally, we are grateful to Michael Thiel, Prof. S. N. Odai (Director, CCLU-KNUST, Kumasi), Dr. W. A. Agyare (Coordinator, CCLUKNUST, Kumasi), Dr. M. I. Ouattara (Director, GSP, WASCAL, Accra) and Dr. L. Sédogo (Executive Director, WASCAL, Accra). We are grateful to the editor and one anonymous reviewer for constructive comments that helped to improve the manuscript.

\section{Competing interests}

The authors declare that they have no competing interests.

Received: 6 April 2016 Accepted: 3 August 2016

Published online: 17 August 2016

\section{References}

1. Houghton RA, House JI, Pongratz J, van der Werf GR, DeFries RS, Hansen $M C$, et al. Carbon emissions from land use and land-cover change. Biogeosciences. 2012;9(12):5125-42. doi:10.5194/bg-9-5125-2012.

2. GOFC-GOLD. A sourcebook of methods and procedures for monitoring and reporting anthropogenic greenhouse gas emissions and removals associated with deforestation, gains and losses of carbon stocks in forests remaining forests, and forestation. GOFC-GOLD Report version COP19-1, GOFC-GOLD Land Cover Project Office, Wageningen University, The Netherlands; 2013.

3. Chave J, Rejou-Mechain M, Burquez A, Chidumayo E, Colgan MS, Delitti $W B$, et al. Improved allometric models to estimate the aboveground biomass of tropical trees. Glob Change Biol. 2015;20(10):3177-90. doi:10.1111/gcb.12629.

4. Baccini A, Goetz SJ, Walker WS, Laporte NT, Sun M, Sulla-Menashe D. Estimated carbon dioxide emissions from tropical deforestation improved by carbon-density maps. Nat Clim Change. 2012;2:182-5. doi:10.1038/ NCLIMATE1354

5. Grassi G, Monni S, Federici S, Achard F, Mollicone D. Applying the conservativeness principle to REDD to deal with the uncertainties of the estimates. Environ Res Lett. 2008;3:035005.

6. Pelletier J, Ramankutty N, Potvin C. Diagnosing the uncertainty and detectability of emission reductions for REDD+ under current capabilities: an example for Panama. Environ Res Lett. 2011;6(2):12. doi:10.1088/1748-9326/6/2/024005.

7. Houghton RA. Aboveground forest biomass and the global carbon balance. Glob Change Biol. 2005;11:945-58. doi:10.1111/j.1365-2486.2005.00955.x.

8. DeFries RS, Houghton RA, Hansen MC, Field CB, Skole D, Townshend J. Carbon emissions from tropical deforestation and regrowth based on satellite observations for the 1980s and 1990s. Proc Natl Acad Sci USA. 2002;99:14256-61.

9. Domke GM, Woodall CW, Smith JE, Westfall JA, McRoberts RE. Consequences of alternative tree-level biomass estimation procedures on US forest carbon stock estimates. For Ecol Manag. 2012;270:108-16. doi:10.1016/j.foreco.2012.01.022.

10. Zianis D, Mencuccini M. On simplifying allometric analyses of forest biomass. For Ecol Manag. 2005;187(2-3):311-32. doi:10.1016/j. foreco.2003.07.007.

11. Ter-Mikaelian MT, Korzukhin MD. Biomass equations for sixty-five North American tree species. For Ecol Manag. 1997;97:1-24. 
12. Jenkins JC, Chojnacky DC, Heath LS, Birdsey RA. Comprehensive database of diameter-based biomass regressions for North American tree species. Newtown Square: Department of Agriculture, Forest Service, Northeastern Research Station; 2004.

13. Eamus D, McGuinness K, Burrows W. Review of allometric relationships for estimating woody biomass for Queensland, the Northern Territory and Western Australia. National carbon accounting system technical report; No. 5B. Australian Greenhouse Office; 2000. ISSN 14426838.

14. Grierson PF, Williams K, Adams MA. Review of unpublished biomassrelated information: Western Australia, South Australia, New South Wales and Queensland. National carbon accounting system technical report No. 25. University of Western Australia. Australian Greenhouse Office; 2000. p. 40.

15. Keith H, Barrett D, Keenan R. Review of allometric relationships for estimating woody biomass for New South Wales, the Australian Capital Territory, Victoria, Tasmania, and South Australia. Canberra: Australian Greenhouse Office; 2000.

16. Jose JJS, Montes RA, Farinas MR. Carbon stocks and fluxes in a temporal scaling from a savanna to a semi-deciduous forest. For Ecol Manag. 1998;105:251-62.

17. Moura-Costa P, Stuart M. Issues related to monitoring, verification and certification of forestry-based carbon offset projects. In: Wood for Africa 99 conference. 1999.

18. Nelson BW, Mesquita R, Pereira JLG, Aquino de Souza SG, Batista GT, Couto LB. Allometric regressions for improved estimate of secondary forest biomass in the central Amazon. For Ecol Manag. 1999;117:149-67.

19. Clark DB, Clark DA. Landscape-scale variation in forest structure and biomass in a tropical rain forest. For Ecol Manag. 2000;137:185-98.

20. Keller M, Palace M, Hurtt G. Biomass estimation in the Tapajos National Forest, Brazil. Examination of sampling and allometric uncertainties. For Ecol Manag. 2001;154:371-82.

21. Fleurant C, Duchesne J, Raimbault P. An allometric model for trees. $J$ Theor Biol. 2004;227:137-47.

22. Chave J, Andalo C, Brown S, Cairns MA, Chambers JQ, Eamus D, et al. Tree allometry and improved estimation of carbon stocks and balance in tropical forests. Ecosyst Ecol. 2005. doi:10.1007/s00442-0050100-x.

23. Akindele SO, LeMay VM. Development of tree volume equations for common timber species in the tropical rain forest area of Nigeria. For Ecol Manag. 2006;226(1-3):41-8. doi:10.1016/j.foreco.2006.01.022.

24. Bakayoko O, Assa AM, Coulibaly B, N'guessan KA. Stockage de Carbone Dans des Peuplements de Cedrela odorataet de Gmelina arboreaen Côte D'ivoire. Eur J Sci Res. 2012;75(4):490-501.

25. Djomo AN, Ibrahima A, Saborowski J, Gravenhorst G. Allometric equations for biomass estimations in Cameroon and pan moist tropical equations including biomass data from Africa. For Ecol Manag. 2010;260(10):1873-85.

26. Djuikouo MNK, Doucet J-L, Nguembou CK, Lewis SL, Sonké B. Diversity and aboveground biomass in three tropical forest types in the Dja Biosphere Reserve, Cameroon. Afr J Ecol. 2010;48:1053-63.

27. Dossa EL, Fernandes ECM, Reid WS, Ezui K. Above- and below-ground biomass, nutrient and carbon stocks contrasting an open-grown and a shaded coffee plantation. Agrofor Syst. 2008;72:103-15.

28. Henry M, Picard N, Trotta C, Manlay RJ, Valentini R, Bernoux M, et al. Estimating Tree biomass of sub-Saharan African forests: a review of available allometric equations. Silva Fenn. 2011;45(3B):477-569.

29. Mbaekwe El, Mackenzie JA. The use of a best-fit allometric model to estimate above ground biomass accumulation and distribution in an age series of teak (Tectona grandis L.f.) plantations at Gambari Forest Reserve, Oyo State, Nigeria. Trop Ecol. 2008;49:259-70.

30. Mbow C, Verstraete MM, Sambou B, Diaw AT, Henry N. Allometric models for aboveground biomass in dry savanna trees of the Sudan and SudanGuinean ecosystems of Southern Senegal. J For Res. 2013;19(3):340-7. doi:10.1007/s10310-013-0414-1.

31. Ngomanda A, Obiang NLE, Lebamba J, Mavouroulou QM, Gomat H, Mankou GS, et al. Site-specific versus pantropical allometric equations: which option to estimate the biomass of a moist central African forest? For Ecol Manag. 2014:312:1-9. doi:10.1016/j.foreco.2013.10.029.

32. Rasmussen MO, Göttsche F-M, Diop D, Mbow C, Olesen F-S, Fensholt $\mathrm{R}$, et al. Tree survey and allometric models for tiger bush in northern Senegal and comparison with tree parameters derived from high resolution satellite data. Int J Appl Earth Obs Geoinf. 2011;13(4):517-27. doi:10.1016/j.jag.2011.01.007.
33. Sawadogo L, Savadogo P, Tiveau D, Sidzabda DD, Zida D, Nouvellet $Y$, et al. Allometric prediction of above-ground biomass of eleven woody tree species in the Sudanian savanna-woodland of West Africa. J For Res. 2010;21(4):475-81. doi:10.1007/s11676-010-0101-4.

34. Shirima DD, Munishi PKT, Lewis SL, Burgess ND, Marshall AR, Balmford A, et al. Carbon storage, structure and composition of Miombo woodlands in Tanzania's Eastern Arc Mountains. Afr J Ecol. 2011;49:332-42.

35. Kuyah S, Dietz J, Muthuri C, Jamnadass R, Mwangi P, Coe R, et al. Allometric equations for estimating biomass in agricultural landscapes: I. Aboveground biomass. Agric Ecosyst Environ. 2012;158:216-24. doi:10.1016/j. agee.2012.05.011.

36. Aholoukpe HB, Flori A, Deleporte P, Amadji G, Chotte JL, Blavet D. Estimating aboveground biomass of oil palm: allometric equations for estimating frond biomass. For Ecol Manag. 2013;292:122-9.

37. Basuki TM, Van Laake PE, Skidmore AK, Hussin YA. Allometric equations for estimating the above-ground biomass in tropical lowland dipterocarp forests. For Ecol Manag. 2009;257(8):1684-94. doi:10.1016/j. foreco.2009.01.027.

38. Li CP, Xiao CW. Above- and belowground biomass of Artemisia ordosica communities in three contrasting habitats of the Mu Us desert, northern China. J Arid Environ. 2007;70(2):195-207. doi:10.1016/j. jaridenv.2006.12.017.

39. Daolan Z, John R, Jiquan C, Thomas C, Mary B, James LM, et al. Estimating aboveground biomass using Landsat 7 ETM+ data across a managed landscape in northern Wisconsin, USA. Int J Remote Sens. 2004;26(12):2509-25.

40. Fonton HN, Dah-Dovono JZ, Adoko FK, Dotchamou T. Modélisation du volume du fût d'arbre pour une gestion durable des écosystèmes forestiers soudaniens. Bois For Trop. 2009;300(2):95-100.

41. García MFA, López SFR, Andrés M, Rubio E, González JJL, de las Heras J. Allometries, biomass stocks and biomass allocation in the thermophilic Spanish juniper woodlands of Southern Spain. For Ecol Manag. 2012;270:85-93. doi:10.1016/j.foreco.2012.01.007.

42. Guendehou GHS, Lehtonen A, Moudachirou M, Mäkipää R, Sinsin B. Stem biomass and volume models of selected tropical tree species in West Africa. South For. 2012;74(2):77-88.

43. Hunter MO, Keller M, Victoria D, Morton DC. Tree height and tropical forest biomass estimation. Biogeosciences. 2013;10(12):8385-99. doi:10.5194/bg-10-8385-2013.

44. Návar-Chaidez J. The spatial distribution of aboveground biomass in tropical forests of Mexico. Trop Subtrop Agroecosyst. 2011;13:149-58.

45. de José JN. Biomass allometry for the tree species of Northern Mexico. Trop Subtrop Agroecosyst. 2010;12(3):507-19.

46. Montagnoli A, Fusco S, Terzaghi M, Kirschbaum A, Pflugmacher D, Cohen WB. Estimating forest aboveground biomass by low density lidar data in mixed broad-leaved forests in the Italian Pre-Alps. For Ecosyst. 2015. doi:10.1186/s40663-015-0035-6.

47. Litton CM, Kauffman JB. Allometric models for predicting aboveground biomass in two widespread woody plants in Hawaii. Biotropica. 2008:40(3):313-20. doi:10.1111/j.1744-7429.2007.00383.x.

48. Ketterings QM, Coe R, van Noordwijk M, Ambagu Y, Palm CA. Reducing uncertainty in use of allometric biomass equations for predicting above-ground tree biomass in mixed secondary forests. For Ecol Manag. 2001;146:199-202.

49. Chen W, Li J, Zhang Y, Zhou F, Koehler K, Leblanc S, et al. Relating biomass and leaf area index to non-destructive measurements in order to monitor changes in Arctic vegetation. Arctic. 2008:62:281-94.

50. Flombaum P, Sala OE. A non-destructive and rapid method to estimate biomass and aboveground net primary production in arid-environments. J Arid Environ. 2007;69:352-8. doi:10.1016/j.jaridenv.2006.09.008.

51. Henry M, Besnard A, Asante WA, Eshun J, Adu-Bredu S, Valentini R, et al. Wood density, phytomass variations within and among trees, and allometric equations in a tropical rainforest of Africa. For Ecol Manag. 2010;260(8):1375-88. doi:10.1016/j.foreco.2010.07.040.

52. Lehtonen A, Mäkipää R, Heikkinen J, Sievänen R, Liski J. Biomass expansion factors (BEFs) for Scots pine, Norway spruce and birch according to stand age for boreal forests. For Ecol Manag. 2004;188(1-3):211-24. doi:10.1016/j.foreco.2003.07.008.

53. Montes N, Gauquelin T, Badri W, Bertaudie V, Zaoui EH. A non-destructive method for estimating above-ground forest biomass in threatened woodlands. For Ecol Manag. 2000;130:37-46. 
54. Nogueira EM, Fearnside PM, Nelson BW, França MB. Wood density in forests of Brazil's 'arc of deforestation': implications for biomass and flux of carbon from land-use change in Amazonia. For Ecol Manag. 2007;248(3):119-35. doi:10.1016/j.foreco.2007.04.047.

55. Tackenberg O. A new method for non-destructive measurement of biomass, growth rates, vertical biomass distribution and dry matter content based on digital image analysis. Ann Bot. 2007;99(4):777-83. doi:10.1093/ aob/mcm009.

56. Chave J, Muller-Landau H, Baker TR, Easdale TA, Teege HT, Webb CO. Regional and phylogenetic variation of wood density across 2456 neotropical tree species. Ecol Appl. 2006;16(6):2356-67.

57. Sallenave P. Propriétés Physiques et Mécaniques des Bois. Nogent sur Marne: CTFT; 1955.

58. Sallenave P. Propriétés Physiques et Mécaniques des Bois. Nogent sur Marne: CTFT; 1964.

59. Von MHJ. Arbres et Arbustes du Sahel: Leurs caracteristiques et leurs utilisations. Germany. Deutsche Gesellschaft fur Technische Zusammenarbeit (GTZ) GmbH; 1983.

60. Carsan S, Orwa C, Harwood C, Kindt R, Stroebel A, Neufeldt H, et al. African wood density database. World Agroforestry Centre, Nairobi; 2012.

61. Oey DS. Specific gravity of Indonesian woods and its significance for practical use. In: Soewarsono PH, Department FF, editors. Bogor: Forest Research Institut. Indonesia; 1951. p. 183.

62. Little ELJ, Wadesworth FH. Common trees of Puerto Rico and the Virgin Islands. Washington, DC: US Department of Agriculture, US Government Printing Office, Superintendent of Documents; 1964.

63. Segura M. Allometric models for tree volume and total aboveground biomass in a tropical humid forest in Costa Rica. Biotropica. 2005;37(1):2-8.

64. Levy PE, Hale SE, Nicoll BC. Biomass expansion factors and root: shoot ratios for coniferous tree species in Great Britain. Forestry. 2004;77(5):42130. doi:10.1093/forestry/77.5.421.

65. Magalhães TM, Seifert T. Tree component biomass expansion factors and root-to-shoot ratio of Lebombo ironwood: measurement uncertainty. Carbon Balanc Manag. 2015. doi:10.1186/s13021-015-0019-4.

66. Nagelkerke NJD. A note on a general definition of the coefficient of determination. Biometrika. 1991;78(3):691-2. doi:10.1093/biomet/78.3.691.

67. Brown S. Estimating biomass and biomass change in tropical forests: a primer. Food and Agriculture Organization of the United Nations, Rome, Italy. Forestry Paper 134; 1997. ISBN 92-5-103955-0.

68. McKee TB, Kleist JNJD. The relationship of drought frequency and duration to time scales. In: Eighth conference on applied climatology, vol 1, p. 17-22; 1993.

69. Team RC. R: a language and environment for statistical computing. Vienna: R Foundation for Statistical Computing; 2003.

70. Liaw A, Wiener M. Classification and regression by randomForest. R News. 2002;2(3):18-22.

71. Foody GM. Status of land cover classification accuracy assessment. Remote Sens Environ. 2002;80:185-201.

72. Pearson TRH, Brown SL, Richard AB. Measurement guidelines for the sequestration of forest carbon. Newtown Square: USDA Forest Service; 2007.

73. Curtis JT. The use of distance measures in phytosociological sampling. Ecology. 1956;37(3):451-61.

74. Schoroth G, D'Angelo SA, Teixeira WG, Haag D, Leiberei R. Conversion of secondary forest into agroforestry and monoculture plantations in Amazonia: consequences for biomass, litter and soil carbon stocks after 7 years. For Ecol Manag. 2002;163:131-50.

75. R Core Team. R: a language and environment for statistical computing. Copyright (1999-2012) R Foundation for Statistical Computing. Vienna, Austria; 2014
76. McCullagh P, Nelder JA. Generalized linear models. Boca Raton: CRC Press; 1989. p. 37.

77. Sugiura N. Further analysis of the data by Akaike's information criterion and the finite corrections. Commun Stat Theory Methods. 1978;A7:13-26.

78. Burnham KP, Anderson DR. Multimodel inference: understanding AIC and BIC in model selection. Sociol Methods Res. 2004;33:261-304.

79. Montagu KD, Düttmer K, Barton CVM, Cowie AL. Developing general allometric relationships for regional estimates of carbon sequestration an example using Eucalyptus pilularis from seven contrasting sites. For Ecol Manag. 2005;204(1):115-29. doi:10.1016/j.foreco.2004.09.003.

80. Sidzabda DD, Houria D, Mathurin Z, Louis S, Louis V. Biodiversity and carbon stocks in different land use types in the Sudanian Zone of Burkina Faso, West Africa. Agric Ecosyst Environ. 2016;61-72. doi:10.1016/j. agee.2015.09.023.

81. Georgii AA. Carbon stock growth in a forest stand: the power of age. Carbon Balanc Manag. 2007;2:4. doi:10.1186/1750-0680-2-4.

82. Bruce $D$, Max TA. Use of profile equations in tree volume estimation. USDA Forest Service general technical report PNW-GTR-Pacific Northwest Research Station (USA); 1990.

83. Schumacher P, Mislimshoeva B, Brenning A, Zandler H, Brandt M, Samimi C, Koellner T. Do red edge and texture attributes from high-resolution satellite data improve wood volume estimation in a semi-arid mountainous region? Remote Sens. 2016;8:540. doi:10.3390/rs8070540.

84. Sarker LR, Nichol JE. Improved forest biomass estimates using ALOS AVNIR-2 texture indices. Remote Sens Environ. 2011;115:968-77.

85. Lu D. The potential and challenge of remote sensing-based biomass estimation. Int J Remote Sens. 2006:27:1297-328.

86. Avitabile V, Baccini A, Friedl MA, Schmullius C. Capabilities and limitations of Landsat and land cover data for aboveground woody biomass estimation of Uganda. Remote Sens Environ. 2012;117:366-80.

87. Pettorelli N, Vik JO, Mysterud A, Gaillard J, Tucker CJ, Stenseth NC, Lyon CB. Using the satellite-derived NDVI to assess ecological responses to environmental change. Trends Ecol Evol. 2005;20:503-10. doi:10.1016/j. tree.2005.05.011.

88. Tucker CJ. Red and photographic infrared linear combinations for monitoring vegetation. Remote Sens Environ. 1979;8:127-50.

89. Hartigan JA, Wong MAA. K-means clustering algorithm. Appl Stat. 1979;28:100-8.

90. Hastie T, Tibshirani R, Friedman J. The elements of statistical learningdata mining, inference, and prediction. Berlin: Springer; 2009.

91. James GM, Witten D, Hastie T, Tibshirani R. An introduction to statistical learning: with applications in R. Berlin: Springer; 2013. doi:10.1007/978-1-4614-7138-71.

92. Doktor D, Lausch A, Spengler D, Thurner M. Extraction of plant physiological status from hyperspectral signatures using machine learning methods. Remote Sens. 2014;6:12247-74. doi:10.3390/rs61212247.

93. Gislason PO, Benediktsson JA, Sveinsson JR. Random forests for land cover classification. Pattern Recognit Lett. 2006;27:294-300. doi:10.1016/j. patrec.2005.08.011.

94. Pal M. Random forest classifier for remote sensing classification. Int J Remote Sens. 2005;26:217-22. doi:10.1080/01431160412331269698.

95. IPCC. 2006 IPCC guidelines for national greenhouse gas inventories. In: Eggleston HS, Buendia L, Miwa K, Ngara T, Tanabe K, editors. Prepared by the national greenhouse gas inventories programme, Technical Support Unit. 2006. ISBN 4-88788-032-4. 